\title{
A case study: consequences of ANTI-TNF $\alpha$ therapy and foot ulcerations. A patient with Ankylosing Spondylitis (AS) treated with Infliximab
}

\author{
Lucy Edgson ${ }^{*}$, Robert Field ${ }^{1}$, Sarah Westlake ${ }^{2}$ \\ From Society of Chiropodists and Podiatrists Annual Conference 2010 \\ Bournemouth, UK. 21-23 October 2010
}

\section{Introduction}

The BSR Biologics Register demonstrates increased risk of serious soft tissue infections in anti-TNF $\alpha$ managed patients. Mobility levels may increase with successful symptom management. However patients' feet present with a combination of foot deformity and compromised tissue viability, with associated risk of ulceration and concomitant infection.

\section{Case presentation}

A 50 year old male with AS presented with foot ulceration and cellulitis, following Infliximab administration. Management involved multiple antibiotics for recurrent infections and weekly podiatric care. Infliximab was stopped, leading to a flare of his arthritis and deteriorating gait and posture, complicating wound management. Active inflammation contributed to impaired wound healing.

After 8 months the patient remains off therapy. Although the chronic ulcer is improving, frequent wound / foot care is required. MRI and X-rays have been used to monitor for bone and joint sepsis.

\section{Discussion}

This case demonstrates the impact of anti-TNF $\alpha$ in the presence of a foot wound. Multiple complications occur from the presence of infection and drug withdrawal. Rest increases joint stiffness and pain. It can be difficult to distinguish between infection \& disease related inflammation. Drug benefits make patients reluctant to

${ }^{1}$ Bournemouth and Poole Community Health Services, Bournemouth, UK Full list of author information is available at the end of the article report foot problems, although in this case it was patient lack of understanding.

\section{Author details}

${ }^{1}$ Bournemouth and Poole Community Health Services, Bournemouth, UK. ${ }^{2}$ Poole General Hospital, Dorset, UK.

Published: 20 December 2010

\section{doi:10.1186/1757-1146-3-S1-P6}

Cite this article as: Edgson et al:: A case study: consequences of ANTITNF $\alpha$ therapy and foot ulcerations. A patient with Ankylosing Spondylitis (AS) treated with Infliximab. Journal of Foot and Ankle Research 2010 3(Suppl 1):P6.
Submit your next manuscript to BioMed Central and take full advantage of:

- Convenient online submission

- Thorough peer review

- No space constraints or color figure charges

- Immediate publication on acceptance

- Inclusion in PubMed, CAS, Scopus and Google Scholar

- Research which is freely available for redistribution 